(C) 2019 International Journal of Nursing and Midwifery Science (IJNMS)

This is an Open Access article distributed under the terms of the Creative Commons Attribution 4.0 International License which permits unrestricted non-commercial use, distribution, and reproduction in any medium, provided the original work is properly cited.

\title{
LEVELS OF DIABETES BLOOD SUGAR WITH TYPE OF CATARACT
}

Indah Lestari ${ }^{1}$, Fifiyahpuahsari ${ }^{2}$

${ }^{1,2}$ STIKes Bina Sehat PPNI Mojokerto

Email: ns.indah@yahoo.com ${ }^{*}$, fifiyahpuahsari@gmail.com

\section{ABSTRACT}

Diabetes mellitus was a disease with macro and micro risk of angiopathy, which includes the impact of causing cataracts. Diabetic patients with high sugar levels have a greater chance of developing cataracts at a younger age and certain tendencies towards cataract type. The aim of the study was to analyze the correlation between diabetes blood sugar levels and cataract type. The research design was correlation analysis with Cross-Sectional approach. Samples in the study were some cataract patients who had a history of diabetes mellitus in Surabaya Undaan Eye Hospital as many as 125 people, it was taken using consecutive sampling technique, and fulfilling the criteria of the study (age range 45 - 65 years, have complete medical records related to the continuity of sugar examination results in blood, the incidence of cataracts is not caused by congenital cataracts, juveniles, due to trauma, chemical exposure to UV radiation). Independent variable was the blood sugar level of Diabetes mellitus and the Dependent variable was cataract type. The instruments used were laboratory tests related to blood sugar levels, and medical diagnosis related to cataract type. Data were analyzed by Spearman rho, with a significant value $<0.05$. The results showed a close association between diabetes and cataracts, where as many as $47.2 \%$ with high blood sugar levels, $40 \%$ with nuclear cataract type and from 59 respondents with high blood sugar levels 26 people experienced nuclear cataract type, with rho value $=0.001$. The mechanism of glucose toxicity in Diabetes Mellitus which causes cataracts can go through three paths: increased activity of the aldose reductase enzyme which causes the formation of sugar alcohol, sorbitol and galactitol in crystalline lenses; through the non-enzymatic replication process; and at high blood glucose levels a glucose oxidation process will occur which causes oxidative stress conditions. Maintenance of managing blood sugar levels must be a concern for diabetics.

\section{Keywords}

Blood Sugar

Level,

Diabetes

Mellitus,

Type of

Cataract 


\section{INTRODUCTION}

Cataracts are a condition of opacity of the eye lens that can be caused by various changes in conditions such as the aging process, exposure to ultraviolet light, systemic diseases of Diabetes Mellitus and become a major cause of blindness in the world (Uspal \& Schapiro, 2011). Cataracts caused by diabetes mellitus are called diabetic cataracts that occur due to changes in the trajectory of sorbitol (polyol) in the eyepiece. The accumulation of sorbitol in the lens of the eye will cause osmotic cell injury which will eventually give opacity to the lens (Ilyas, 2017).

Cataracts are still one of the most in the world. It is estimated that every year there will be one new cataract patient in 1,000 people. Data owned by WHO (2015) shows that the estimated number of people with visual impairments worldwide is 285 million, with cataracts being the biggest cause $(51 \%)$. In Indonesia, cataract is the main cause of blindness, national cataract prevalence is 1.8 percent, the prevalence of cataracts at the age of $55-65$ is $70.5 \%$, age $65-75$ years is $3.9 \%$, and age 75 years and over at $2.5 \%$. In addition to the fact that the total number of cataract surgeries is still small, the high number of cataract sufferers in Indonesia is associated with a very wide population spread (Kesehatan \& Indonesia, n.d.).

In East Java, cataracts still have a very high prevalence of $4.4 \%$ of people aged 50 years, throughout East Java with rates reaching 40 million or 120 thousand cataract patients (Lingkungan \& Nugrahalia, 2016). Surabaya Undaan Eye Hospital in 2016 the number of cataract patients reached 25,827 patients, and in 2017 there was an increase of 26,299 cataract patients, where in the diagnosis of doctors in getting cataracts was 45 patients, and diabetic cataracts were 70 patients.

Someone with uncontrolled diabetes has a high risk of developing cataracts. This risk increases because high blood glucose levels can cause the lens of the eye to swell. Diabetes can also cause a substance called sorbitol to accumulate in the eye, so it can make the lens less clear and opaquer (Klein, Klein, \& Lee, 1998).

Blood glucose in the body stimulates the pancreas to produce enough insulin in the body and makes insulin work increase. Glucose conditions that continue to rise, while the pancreas is not able to produce enough insulin to make the accumulation of glucose in the blood and disrupt blood circulation in the blood vessels making the body's metabolism unbalanced causing long-term complications that cause damage to blood vessels in the eye and cause cataracts (Borenshtein, 2001); (Li, Wan, \& Zhao, 2014).

Although diabetics have a higher risk of vision problems, problems can be avoided and prevented. This research contributes to the understanding of the community, that by recognizing the risks and types of cataracts, they will be motivated to manage blood sugar levels within normative limits.

\section{MATERIALS AND METHODS}

The research design is correlation analysis with Cross-Sectional approach. Samples in the study were some cataract patients who had a history of diabetes mellitus in Surabaya Undaan Eye Hospital as many as 125 people, were taken using consecutive sampling technique, and fulfilled the study criteria (age range 45 - 65 years, had complete medical records related to the continuity of sugar examination results from blood, the incidence of cataracts is not caused by congenital cataracts, juveniles, due to trauma, chemical exposure to UV radiation). Independent variable is the blood sugar level of diabetic's mellitus and the Dependent variable is cataract type. The instruments used were laboratory tests related to blood sugar levels, and medical diagnosis related to cataract type. Data were analyzed by Spearmen rho, with a significant value $<0.05$. 
RESULTS

Characteristics of Respondents in Poly Eye - Surabaya Undaan Hospital

\begin{tabular}{llll}
\hline $\mathbf{N}$ & $\begin{array}{l}\text { Characterist } \\
\text { ic }\end{array}$ & $\begin{array}{l}\text { Frequenc } \\
\mathbf{y}\end{array}$ & $\begin{array}{l}\text { Percentag } \\
\mathbf{e}(\mathbf{\%})\end{array}$ \\
\hline $\mathbf{1}$ & Age & & \\
& 30 years old & 1 & 0,8 \\
& 40 years old & 8 & 6,4 \\
& 50 years old & 62 & 49,6 \\
& 60 years old & 50 & 40,0 \\
& 70 years old & 4 & 3,2 \\
\hline
\end{tabular}

2 Gender

$\begin{array}{lll}\text { Male } & 63 & 50,4\end{array}$

$\begin{array}{lll}\text { female } & 62 & 49,6\end{array}$

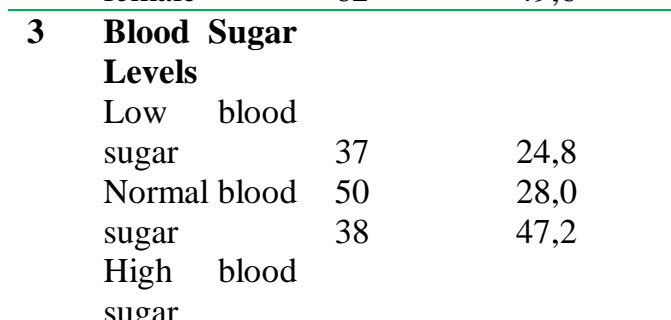

4 Cataract

Criteria

Sukapsular

$\begin{array}{lll}\text { Cataract } & 37 & 29,6\end{array}$

Nuclear $\quad 50 \quad 40,0$

$\begin{array}{lll}\text { Cataract } & 38 & 30,4\end{array}$

Cortical

Cataracts

5 History of

diabetes

mellitus $\quad 28 \quad 22,4$

$<5$ years $\quad 97 \quad 77,6$

$>5$ years

\begin{tabular}{llll}
\hline 6 & Diet B1 - B3 & & \\
& B1 & 51 & 40,8 \\
& B2 & 46 & 36,8 \\
& B3 & 28 & 22,4 \\
\hline 7 & Type of & & \\
& medicine & 22 & 17,6 \\
& Metformin & 23 & 18,4 \\
& Amandiab & 16 & 12,8 \\
& Renabetic & 15 & 12,0 \\
& Glimepiride & 17 & 13,0 \\
& Glance & 13 & 10,4 \\
& Metrix & 12 & 9,6 \\
& Amaryl & 7 & 5,6 \\
& Diaglime & 125 & 100 \\
\hline Total & & \\
\hline
\end{tabular}

The table shows the characteristics of respondents with cataract incidence, has a tendency to be younger (50 years) as many as 62 respondents $(49.6 \%)$, experienced an increase in blood sugar levels as many as 59 respondents $(47.2 \%)$. Most cataract types experienced were nuclear cataracts of 50 respondents $(40.0 \%)$, with a history of diabetes mellitus $>5$ years as many as 97 respondents (77.6\%), most of them underwent a B1 diet of 51 respondents (40.8\%). ), and consumed 23 Amandiab drugs $(18.4 \%)$.

Characteristics of Respondents Based on Blood Sugar Levels in Poly Eye Surabaya Undaan Hospital

\begin{tabular}{|c|c|c|c|}
\hline No & $\begin{array}{l}\text { Blood } \\
\text { sugar level }\end{array}$ & Total & $\begin{array}{l}\text { Percentage } \\
(\%)\end{array}$ \\
\hline 1 & $\begin{array}{l}\text { Low blood } \\
\text { sugar }\end{array}$ & 31 & 24,8 \\
\hline 2 & $\begin{array}{l}\text { Normal } \\
\text { blood sugar }\end{array}$ & 35 & 28,0 \\
\hline 3 & $\begin{array}{l}\text { High blood } \\
\text { sugar }\end{array}$ & 59 & 47,2 \\
\hline & Total & 125 & 100 \\
\hline
\end{tabular}

Based on the table, the majority of respondents with high blood sugar levels were 59 respondents (47.2\%). This illustrates the tendency of the turbidity process in the eyepiece.

Characteristics of Respondents Based on Criteria for Diabetic Cataracts at Poly Eye - Surabaya Undaan Hospital

\begin{tabular}{lllc}
\hline No & $\begin{array}{l}\text { Cataract } \\
\text { Criteria }\end{array}$ & Total & $\begin{array}{l}\text { Percentage } \\
(\%)\end{array}$ \\
\hline 1 & $\begin{array}{l}\text { Subcapsular } \\
\text { Cataract }\end{array}$ & 37 & 29,6 \\
\hline 2 & $\begin{array}{l}\text { Nuclear } \\
\text { Cataract }\end{array}$ & 50 & 40,0 \\
\hline 3 & $\begin{array}{l}\text { Cortical } \\
\text { Cataracts }\end{array}$ & 38 & 30,4 \\
\hline & Total & 125 & 100
\end{tabular}

In the table, there are 50 respondents $(40.0 \%)$ experiencing nuclear cataract as a result of diabetes. 
Cross Tabulation Between the Relationship of Blood Sugar Levels with Cataract Criteria in Patients with Diabetes Mellitus at Poly Eye - Surabaya Undaan Hospital

\begin{tabular}{|c|c|c|c|c|c|c|c|c|c|}
\hline \multirow{3}{*}{$\begin{array}{l}\mathrm{N} \\
\mathrm{O}\end{array}$} & \multirow{3}{*}{$\begin{array}{l}\text { Blo } \\
\text { od } \\
\text { sug } \\
\text { ar } \\
\text { lev } \\
\text { el }\end{array}$} & \multicolumn{6}{|c|}{ Cataract Criteria } & \multirow{2}{*}{\multicolumn{2}{|c|}{ Total }} \\
\hline & & \multicolumn{2}{|c|}{$\begin{array}{l}\text { Sukaps } \\
\text { ular } \\
\text { Catara } \\
\text { ct }\end{array}$} & \multicolumn{2}{|c|}{$\begin{array}{l}\text { Nucle } \\
\text { ar } \\
\text { Catar } \\
\text { act }\end{array}$} & \multicolumn{2}{|c|}{$\begin{array}{l}\text { Cortic } \\
\text { al } \\
\text { Catar } \\
\text { acts }\end{array}$} & & \\
\hline & & $\mathrm{F}$ & $\%$ & $\mathrm{~F}$ & $\%$ & $\mathrm{~F}$ & $\%$ & $\mathrm{~F}$ & $\%$ \\
\hline 1 & $\begin{array}{l}\text { Lo } \\
\text { w } \\
\text { blo } \\
\text { od } \\
\text { sug } \\
\text { ar }\end{array}$ & $\begin{array}{l}1 \\
2\end{array}$ & $\begin{array}{l}47, \\
8\end{array}$ & $\begin{array}{l}1 \\
1\end{array}$ & $\begin{array}{l}4 \\
6, \\
3\end{array}$ & 8 & $\begin{array}{l}5, \\
9\end{array}$ & $\begin{array}{l}3 \\
1\end{array}$ & $\begin{array}{l}1 \\
0 \\
0\end{array}$ \\
\hline 2 & $\begin{array}{l}\text { Nor } \\
\text { mal } \\
\text { blo } \\
\text { od } \\
\text { sug } \\
\text { ar }\end{array}$ & $\begin{array}{l}1 \\
2\end{array}$ & $\begin{array}{l}33, \\
3\end{array}$ & 9 & $\begin{array}{l}2 \\
0, \\
0\end{array}$ & $\begin{array}{l}1 \\
4\end{array}$ & $\begin{array}{l}4 \\
6, \\
7\end{array}$ & $\begin{array}{l}3 \\
5\end{array}$ & $\begin{array}{l}1 \\
0 \\
0\end{array}$ \\
\hline 3 & $\begin{array}{l}\text { Hig } \\
\mathrm{h} \\
\text { blo } \\
\text { od } \\
\text { sug } \\
\text { ar }\end{array}$ & $\begin{array}{l}2 \\
6\end{array}$ & $\begin{array}{l}48, \\
2\end{array}$ & $\begin{array}{l}1 \\
8\end{array}$ & $\begin{array}{l}2 \\
7, \\
0\end{array}$ & $\begin{array}{l}1 \\
5\end{array}$ & $\begin{array}{l}2 \\
4, \\
8\end{array}$ & $\begin{array}{l}5 \\
9\end{array}$ & $\begin{array}{l}1 \\
0 \\
0\end{array}$ \\
\hline & Total & $\begin{array}{l}5 \\
0\end{array}$ & $\begin{array}{l}46, \\
9\end{array}$ & $\begin{array}{l}3 \\
8\end{array}$ & $\begin{array}{l}2 \\
9 \\
8\end{array}$ & $\begin{array}{l}3 \\
7\end{array}$ & $\begin{array}{l}2 \\
3, \\
3\end{array}$ & $\begin{array}{l}1 \\
2 \\
5\end{array}$ & 1 \\
\hline
\end{tabular}

Result spearman rho $=0.001$

Based on the table it appears on respondents with high blood sugar levels (> $200 \mathrm{mg} / \mathrm{dl}$ ) to get criteria for nuclear cataract as many as $26(48.2 \%)$ which means cataracts that attack the center of the lens. Unlike when sugar levels are low or normal, the incidence of cataracts is still sub-capsular or coronary.

\section{DISCUSSION}

Diabetes Mellitus is a condition of excessive blood sugar levels, can cause longterm damage, dysfunction, and failure of various organs, especially the eyes, kidneys, nerves, heart and blood vessels (Narendran et al., 2002). Diabetes mellitus is a metabolic disorder where it is found an inability to oxidize carbohydrates due to interference with the normal mechanism of insulin. People with diabetes mellitus will have higher blood sugar levels than normal people (Papers \& No, 2010). In type 1 DM there is an autoimmune process caused by inflammation in beta insulitis cells while type $2 \mathrm{DM}$ has two main problems related to insulin, namely insulin resistance and insulin secretion disorders. Normally insulin will be bound to special receptors on the cell surface. As a result of the binding of insulin to these receptors, a series of glucose metabolic reactions occur in the cell (Murtha \& Cavallerano, 2007); ("The Influence of Age , Duration of Diabetes , Cataract , and Pupil Size on," 2005). Insulin resistance in type $2 \mathrm{DM}$ is accompanied by a decrease in intracellular reactions. Thus insulin becomes ineffective for stimulating glucose uptake by tissues. This condition gives two times the risk of experiencing turbidity in the eyepiece (Grauslund, Green, \& Sjølie, 2011).

The eyepiece is an avascular organ that is located in the back of the eye chamber and in the front is surrounded by aquosine liquid. This aquatic liquid is a source of nutrition for the lens and also functions as a reservoir of metabolites excreted by the surrounding tissue. Unlike the other cells, glucose can enter the eye lens freely, through a process of diffusion without the help of insulin (Theodoropoulou, Theodossiadis, Vergados, \& Lagiou, 2011). Inside the lens glucose breakdown is mostly $(78 \%)$ via the anaerobic glycolysis pathway, $14 \%$ through the pentose phosphate pathway and about $5 \%$ via the polyol pathway. In conditions of hyperglycemia, anaerobic glycolysis pathways are saturated quickly, and glucose will choose the polyol pathway. In the polyol pathway glucose is converted into sorbitol, which is the form of alcohol. Here sorbitol should then be broken down into fructose by the Polyol Dehydrogenase enzyme, but in Diabetes Mellitus the levels of Polyol Dehydrogenase enzymes are low so sorbitol builds up in the lens of the eye. This results in a hypertonic condition that will pull in the acoustical fluid into the lens of the eye, damage the lens architecture and there will be turbidity of the lens (cataract osmotic 
theory in Diabetes Mellitus) (Flesner et al., 1997); (Hegde \& Varma, 2005).

The mechanism of glucose toxicity in Diabetes Mellitus which causes cataracts Diabetes can basically go through three pathways, first: due to increased activity of the aldose reductase enzyme which causes the formation of sugar alcohol, sorbitol, and galactitol in crystalline lenses; second: through a nonenzymatic replication process where glucose which has a carbonyl reactive compound $(\mathrm{C}=\mathrm{O})$ will bind to the amino group crystalline protein (-NH2). This reaction will cause a decrease in protein solubility; third: at high blood glucose levels there will be a gluten-oxidation process that causes oxidative stress conditions (Kim, Kim, \& Chung, 2012); (Narendran et al., 2002).

The cohort study by the Beaver Dam Eye Study states that diabetes mellitus is associated with the incidence and course of subcapsular, nuclear and cortical posterior cataracts. The results of the study showed a tendency of 26 respondents $(48.2 \%)$ with nuclear cataract criteria. Nuclear cataracts tend to be progressively slow, and typically result in greater long-distance visual impairment of close-range vision (Chung, Kim, Kim, Yoo, \& Lee, 2002). This is due to the increased focus strength of the lens of the central part which causes refraction to shift to myopia. These symptoms can include poor color discrimination or monocular diplopia. Some nuclear cataracts are bilateral, but can be asymmetrical (Lee, Grossman, Arnold, \& Sloan, 2011). Nuclear cataracts also increase the greater risk of covering the lens faster than other cataract criteria, because nuclear cataracts attack the center of the lens of the eye (Olafsdottir, Andersson, \& Stefa, 2012).

\section{CONCLUSIONS}

This study shows that diabetes and cataracts are strongly related. That 1) The higher the blood sugar level the greater the risk of lens opacities or cataracts quickly, 2) The type of cataract most often experienced as a result of diabetes is nuclear cataracts, 3) Long history of diabetes mellitus can cause a build up of blood sugar levels in the eyepiece and if uncontrolled blood sugar levels can be at a faster risk of causing turbidity in the lens or cataracts, 4) Use of oral hypoglycemic drugs and the use of insulin proved to have an important role in cataract formation in patients with diabetes mellitus and can be at risk for nuclear cataracts.

\section{REFFERENCES}

Borenshtein, D. (2001). Cataract development in diabetic sand rats treated with a -lipoic acid and its $\mathrm{c}$ linolenic acid conjugate, 7560(August 2000), 44-50.

Chung, J., Kim, M., Kim, H., Yoo, J., \& Lee, Y. (2002). Effect of cataract surgery on the progression of diabetic retinopathy, 3350(1).

Flesner, P., Sander, B., Henning, V., Parving, H., Dornonville, M., Cour, D., \& Lund-andersen, H. (1997). Cataract surgery on diabetic patients . A prospective evaluation of risk factors and complications, 19-24.

Grauslund, J., Green, A., \& Sjølie, A. K. (2011). Cataract surgery in a population-based cohort of patients with type 1 diabetes: long-term incidence and risk factors, 25-29. https://doi.org/10.1111/j.1755-

3768.2009.01619.x

Hegde, K. R., \& Varma, S. D. (2005). Cataracts in experimentally diabetic mouse : morphological and apoptotic changes, 200-204. 
https://doi.org/10.1111/j.1463

Ilyas, S. (2017). Ilmu Penyakit Mata (edisi

5). Jakarta: Balai Penerbit FKUI.

Kesehatan, K., \& Indonesia, R. (n.d.). No Title.

Kim, B., Kim, S. Y., \& Chung, S. K. (2012). Changes in apoptosis factors in lens epithelial cells of cataract patients with diabetes mellitus. Journal of Cartaract \& Refractive Surgery, 38(8), 1376-1381. https://doi.org/10.1016/j.jcrs.2012.0 4.026

Klein, B. E. K., Klein, R., \& Lee, K. E. (1998). Barbara e. k. klein, md, ronald klein, md, and kristine e. lee, ms, 9394(98).

Lee, M. S., Grossman, D., Arnold, A. C., \& Sloan, F. A. (2011). Incidence of Nonarteritic Anterior Ischemic Optic Neuropathy: Increased Risk Among Diabetic Patients. ОРНТНА, 118(5), 959-963. https://doi.org/10.1016/j.ophtha.20 11.01 .054

Li, L., Wan, X., \& Zhao, G. (2014). Metaanalysis of the risk of cataract in type 2 diabetes, (4).

Lingkungan, J. B., \& Nugrahalia, M. (2016). BioLink HUBUNGAN KATARAK SENILIS DENGAN KADAR GULA DARAH PADA
PENDERITA

DIABETES

MELLITUS DI MEDAN Relations with Senile Cataract Blood Sugar Levels in Patients Diabetes Mellitus in Medan, 2(2), 110-116.

Murtha, T., \& Cavallerano, J. (2007). The management of diabetic eye disease in the setting of cataract surgery.

Narendran, V., John, R. K., Raghuram, A., Ravindran, R. D., Nirmalan, P. K., \& Thulasiraj, R. D. (2002). Diabetic retinopathy among self reported diabetics in southern India: a population based assessment, (4), 1014-1018.

Olafsdottir, E., Andersson, D. K. G., \& Stefa, E. (2012). The prevalence of cataract in a population with and without type 2 diabetes mellitus, 334-340.

https://doi.org/10.1111/j.1755-

3768.2011.02326.x

Papers, I., \& No, R. (2010). Prevalence and Risk Factors for Cataract in Diabetes., (17), 1-31.

The Influence of Age, Duration of Diabetes , Cataract, and Pupil Size on. (2005), 28(10).

Theodoropoulou, S., Theodossiadis, P., Vergados, I., \& Lagiou, P. (2011). The epidemiology of cataract: a study in Greece, 167-173. https://doi.org/10.1111/j.1755- 
3768.2009.01831.x

Uspal, N. G., \& Schapiro, E. S. (2011).

Cataracts as the Initial

Manifestation of Type 1 Diabetes

Mellitus, 27(2), 132-134.

International Journal Of Nursing and Midwifery Science (IJNMS), Volume3, Issue1, April 2019 